\title{
DETERMINANTS OF PERFORMANCE OF ASSISTANT DISTRICT VALUERS IN THE DEPARTMENT OF VALUATION IN SRI LANKA
}

Dissertation submitted to the University of Sri Jayewardenepura as a partial fulfillment for the requirements of the final examination of the M.Sc. in Real Estate Management and Valuation Degree.

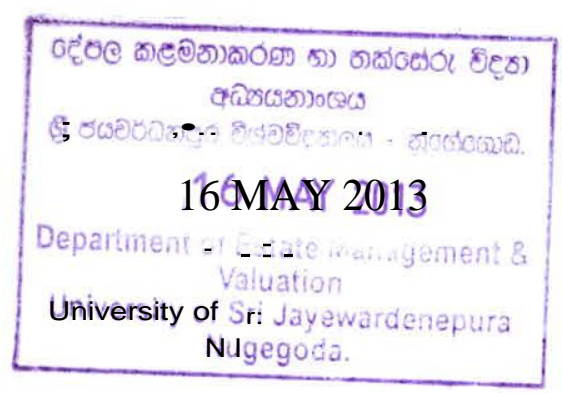

$\begin{array}{ll}\text { Full Name } & \text { : R.A.R.M.NIMAL RAJAKARUNA } \\ \text { Examination No } & \text { : REMV/ 80 } \\ \text { Registration No } & \text { : GS/M.Sc/REMV 3768 / } 09 \\ \text { Department } & \text { : Estate Management and Valuation } \\ \text { University } & \text { : Sri Jayawardenepura } \\ \text { DatteSfublmixisioion } & \text { : 28 } \\ \end{array}$


The work describes in this dissertation was carried out under the supervision of Professor (Dr.) R.Lalitha S.Fernando and any report on this has not been submitted in whole or in part to any university or any other institute for another degree / examination or any other purpose.

Full Name

Examination No

Signature of the Candidate

Date
: R A R M NIMAL RAJAKARUNA

: REMV / 80
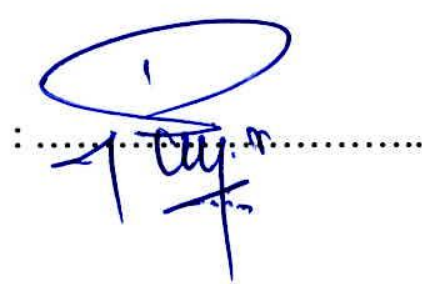

: 28.01.2013 
Hereby, I certify that Mr. R A R M Nimal Rajakaruna, (GS / M.Sc / REMV 3768 / 09 duly completed the research titled "Determinants of Employee Performance in the Department of Valuation in Sri Lanka " under my supervision and recommended to submit for the evaluation.

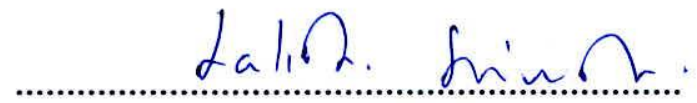

Signature of the supervisor Departmen: of Public Administration University of Sri Jayewardenepura Nugegoda, Sri Lanka.

Signature of the $2^{\text {nd }}$ examiner

Signature and the official stamp of the Head of the Department 


\begin{abstract}
Although the volume of literature on employee performance management, performance evaluation, employee motivation factors and satisfaction factors grows, apparently researchers pay scant attention on determinants of employee performance in the government sector service organizations.
\end{abstract}

As a government sector service organization the Department of Valuation faces problems on low performance of its employees who work as Assistant District Valuers (ADVs).Hence researcher paid much attention on that matter and selected as the research problem. The objectives of this research are to investigate and identify the key determinants pertaining to the performance of ADVs and establish a high performance culture in the Department of Valuation.

The determinants such as Support of Supervisors, Knowledge and Skills of Employees, Working Conditions, Feedback on Job Results, Non-financial Rewards, Efficiency of Existing Performance Rating System were identified in the process of the research, based on data collected from a pilot survey, literature and the experience of the researcher. The primary data was collected through a self questionnaire from ADVs who were selected through a systematic random sampling method and the secondary data was obtained from the records and reports of the Valuation Department.

The reliability of the data set was tested using the Cronbatch's alpha for the purpose of increasing the validity of the study. Then the analysis of correlation, ANOVA and multiple regressions were used as analytical tools to identify the key determinants. Finally tested the hypotheses to investigate the relationship between selected determinants and employee performance.

The result of the analysis shows that the determinants (a) support of supervisors, (b) working conditions significantly affected the performance of ADVs, the remaining four were not found to be of much influence on their performance. Having done the identification of the factors affect to the low performance of the ADVs, researcher proposed and recommends the proposals to increase the performance to achieve the desired galls of the Department. 


\section{ACKNOWLEDGEMENT}

In the first instants, I would like to thank the Department of Valuation for allowing me to do this study. Secondly, I would be grateful to my supervisor, Professor (Dr.) R. Lalitha S. Fernando for her invaluable advice, intellectual guidance and supervision, which cannot be exhaustively substantiated and also which has been a source of inspiration to me throughout the whole Thesis Writing Process.

I also acknowledge the invaluable guidance provided by Professor R.G. Ariyawansa, current course coordinator Mrs. Padma Weerakoon, and the immediate past course coordinator Mrs.Nishani Wickramarachchi and all other lecturers of the Master Programme and I would like to thank the administration staff for their genuine help and support throughout my study period. I am also grateful for my colleagues of the Master Programme for their invaluable support and contribution during the dissertation seminars and also for the thesis writing process.Their constructive comments have always been a motivating factor in improving my work.

I wish to take this opportunity to thank the staff at Kandy office and the Regional valuers and their staff for their continuous support and assistance during the data collection and my whole study period. I greatly appreciate for spending their precious time and support for the same.

Last but not least, I want to express my heartfelt thanks to my family for their dearly care and encouragement throughout my study period. 


\section{Abbreviations}

ADV- Assistant District Valuer

BARS-Behaviorally Anchored Rating Scales

BSC (E.M.V)-Bachelor of Science (Estate Management and Valuation)

DV- District Valuer

FB- Feedback on job results

GRS- Graphic rating scale

HRM- Human Resource Management

IT- Information and technology

MBO- Management by objective

MBO- Management by objective

NFR- Non Financial Rewards

PA- Performance appraisal

PER- Performance appraisal rating

RICS- Royal Institute of Charted Surveyors

KS- Knowledge and Skills

SS- Support of Supervisor

WC- Working Condition 


\section{Table of Contents}

Abstract $i$

Acknowledgement ii

List of abbreviations $\quad$ iii

Table of Contents iv, $v$,

List of Tables vi,vii,

List of Figures viii

Contents Page

CHAPTER ONE - Introduction $\quad$ 01-10

$\begin{array}{ll}\text { 1.1. Background of the study } & 01\end{array}$

1.2. Problematic statement 02

1.3.The research questions of the study 05

1.4 .Objectives of the study 06

1.5. Significance of the study 06

1.6. Methodology of the Research 07

1.7. Structure of the Thesis 09

CHAPTER TWO - Literature Review 11 - 36

2.1. Introduction 11

2.2. Performance Appraisal 11

2.3. Determinants of Employee Performance 21

2.4. Conceptual Model 31

2.5. Hypothesis development 31

2.6. Operationalization of variables 33

2.7. Summary 36

CHAPTER THREE - Research Design $\quad 37-44$

3.1. Introduction 37

3.2. Research design 37

3.3. Population, sample and sample procedure 38 
3.4. Data 41

3.5. Validity and reliability 43

3.6. Data analysis $\quad 44$

CHAPTER FOUR - Background of the Study $45-54$

4.1. Introduction 46

4.2. Structure of the Department 46

4.3. Services provided by the department 48

4.4. Human Resource management 49

CHAPTER FIVE - Analysis of data and data presentation $\quad 55$ - 89

5.1. Introduction 55

5.2. Data presentation 55

5.3. Descriptive analysis 56

5.4. Analysis and results 82

5.5. Research findings and discussion 86

CHAPTER SIX - Conclusion and Recommendation

6.1. Conclusion 90

6.2. Research findings 91

6.3. Recommendation 92

6.4. Implication for future research 95

List of Reference $\quad 96-98$

$\begin{array}{lr}\text { Annexure } & \text { 99-108 }\end{array}$

I. Questionnaire part 1 and $2 \quad 99-102$

II. Reliability test 103-104

$\begin{array}{ll}\text { III. Correlation analysis } & 105\end{array}$

IV. Regression analysis 106-107

$\begin{array}{ll}\text { V. Performance evaluation criterion } & 108\end{array}$ 


\section{List of Tables}

Table

Page

1.1. Performance Levels of Employees 2

1.2. Selection a sample for an in-depth interview 3

1.3 Criteria of Point allocation 3

2.1. Operationlisation of demographic variables 34

2.2. Operationalisation of research variables 32

3.1. Selecting a sample size $\quad 39$

3.2. Selection of Sample $\quad 40$

3.3. Selection of a sample for the in-depth interview 42

4.1. Office structure and hierarchy 46

4.2. Cadre / Strength of the Department of Valuation 49

4.3. Points allocation $\quad 52$

4.4. Performance measuring standards $\quad 54$

5.1. Educational qualifications 56

5.2. Marital status $\quad 57$

5.3. Gender formation $\quad 58$

5.4. Age of the Assistant District valuers 59

5.5. Experience of Assistant District valuers $\quad 60$

5.6. Promotions 61

5.7. Professional qualifications $\quad 62$

5.8. Attention of supervisor $\quad 63$

5.9. Adequate files $\quad 64$

5.10. Finding faults $\quad 64$

5.11. Better working condition 65

5.12. Equal distribution $\quad 65$

5.13. Progress evaluation 66

5.14. Vision and mission $\quad 66$

$\begin{array}{ll}\text { 5.15. Prioritize of work } & 67\end{array}$

$\begin{array}{ll}\text { 5.16. Oral and written communication skills } & 68\end{array}$

5.17. New tools $\quad 68$

$\begin{array}{ll}\text { 5.18. Computer knowledge } & 69\end{array}$ 
5.19. Problem solving ability 69

5.20. Data base $\quad 70$

5.21. Updating knowledge $\quad 70$

5.22. Convenient work place 71

5.23. Design of office space $\quad 72$

5.24. Design of office space and furniture \& fittings 72

$\begin{array}{ll}\text { 5.25. Pleasant office place } & 73\end{array}$

$\begin{array}{ll}\text { 5.26. Hazardless office space } & 73\end{array}$

5.27. Distance to work place 74

5.28. Transport facilities 74

5.29. Relax around meals 75

5.30. Job security 76

5.31. Training \& Education 76

5.32. Verbal appraisal 77

5.33. Recognition 77

5.34. Encourage by performance 78

5.36. Self evaluation 78

5.37. Acknowledgement of future goals 79

5.38. Accuracy of Performance evaluation $\quad 79$

5.39. Quality of job 80

5.40. Time period $\quad 80$

5.41 Performance of ADVs in $2010 \quad 81$

5.42. Reliability statistics $\quad 82$

5.50. Results of correlation analysis $\quad 83$

5.51. ANOVAs and regression analysis $\quad 84$ 


\section{List of Figures}

Figure Pages

2.1. Conceptual framework 31

2.2. Research definitions 33

4.1. Organization Structure 45

4.2. ADV strength of the Department 49

5.1. Educational qualifications 57

5.2. Marital states 58

5.3. Gender $\quad 59$

5.4. Age of the respondents 60

5.5. Average experiences 61

5.6. Promotions 62

5.7. Professional qualifications 63

5.8. Performance of ADVs in $2010 \quad 81$

5.9. Graphical form of the determinants 87 


\section{CHAPTER ONE}

\section{Introduction}

\subsection{Background to the research}

Performance means how well or badly someone does something or the way a person performs. The performance of every employee in an organization is not completely good or bad. If there is a difference or gap between actual performance and what is desired by the organization, the realization of the objectives of the organization may be adversely affected. Hence the level of performance of employees in any organization is more important than the other production or service factors.

A number of researchers have established the relationship between human resource practices and employee performance. However, little evidence is available on relationships between determinants and employee performance. With the experience of about 30 years in the Department of Valuation as a Valuer, observations of the performance of employees, discussions held with the various level officers in the Department, and studying the literature, 6 determinants were identified to examine in this research i.e. (a) support of supervisors, (b) knowledge, skills of employees, (c) working conditions, (d) non financial rewards, (e) feed-back on job results and (f) efficiency of the existing performance evaluations of Assistant District Valuers (ADVs) in the Department of Valuation.

Satisfactory employee performance helps organizations to achieve their goals and objectives more efficiently and effectively. Further it would benefit the employees in terms of recognition and career development opportunities leading to improved knowledge, skills and attitudes.

Akinyele and Samuel (2007) noted that in recent times, countries of the world are becoming aware that increasing economic growth is not only due to new technology or combination of factors of production but also due to the development of its manpower resources. Further the author emphasized that the human side of an enterprise is an important component of an organization, where the enterprise can obtain the best of human capital for effective organizational performance. 
Employees differ from each other based on their abilities and attitudes. There may be some differences between the quality and quantity of the same work on the same job done by two different people, but if the differences go beyond reasonable limits it may become a problem for the organization. Hence every organization needs to identify the most important determinants of employee performance. Failure to do so would result in the organizations being unable to take timely measures to achieve their desired goals and objectives.

The Department of Valuation assesses the performance of Assistant District Valuers at the end of every month. The total work force of the Department is 438, which consists of managerial and non-managerial staff. Brown and Heywood (2005) define performance appraisal as "formal appraisal of non-managerial workers at least once a year". Assistant District Valuers are considered as non-managerial staff, who is engaged in the operational level under the direct supervision of District Valuers, who are the front line managers of the Department. Hence, in this study only the Assistant District Valuers are considered as the population. They make up the majority of the whole work force, it was $82.20 \%$ in the year 2010 of the Department of Valuation and the proper functioning of the Department depends on their performance to a large extent.

\subsection{Problem statement}

Even though the Department expects a higher performance standard from the Assistant District Valuers, the performance of a majority of them is at an average or below average level. The Department does not expect the level below average as shown in the table 1.1 given below.

\section{Table 1.1 Department expectations}

\begin{tabular}{||l||c|c|}
\hline \multicolumn{1}{|c||}{ Appraisal Rating } & Marks & Levels \\
\hline \hline Excellent & 17.5 or more & Expected levels \\
\cline { 1 - 2 } Above average & 12.50 to 17.50 & Expected levels \\
\cline { 1 - 2 } Average & 10.00 to 12.50 & Unexpected levels \\
\cline { 1 - 2 } Unsatisfactory & Below 10.00 & Unexpected level \\
\hline
\end{tabular}

Source: Departmental order 248 


\subsubsection{Performance Appraisal criteria and standards}

The above rating standards are based on the criterion introduced by the Department in circular No.282 (2006), which is based on the type of job done by Assistant District Valuers during the period of appraisal.

Table 1.2 Criteria of point allocation

\begin{tabular}{|c|c|c|}
\hline \multirow[t]{2}{*}{ Type of work } & \multicolumn{2}{|c|}{ Points } \\
\hline & File & Unit \\
\hline Condition Reports & 0.25 & 0.10 \\
\hline Land Acquisition- General & 3.00 & 0.50 \\
\hline Urban Development Authority & 3.50 & 0.75 \\
\hline National Development Authority & 3.50 & 0.75 \\
\hline Land Estimates & 2.00 & 0.15 \\
\hline Land Miscellaneous & 2.00 & 0.15 \\
\hline Stamp Duty & 2.00 & 0.15 \\
\hline Bribery cases & 4.00 & 0.00 \\
\hline Rental Private & 1.00 & 0.05 \\
\hline Re assessment & - & 0.10 \\
\hline Building application & - & 0.15 \\
\hline Rating objections & - & 0.05 \\
\hline Rating-Preliminary survey & - & 0.03 \\
\hline New card system & - & 0.015 \\
\hline Final Survey & - & 0.006 \\
\hline Special Properties & - & 0.75 \\
\hline Rent board meetings(per sitting) & - & 0.30 \\
\hline Land Acquisition Board of Review & - & .60 per day \\
\hline Preparation of files & 3.00 & $.6-$ per day \\
\hline Attendance on appeals(per day) & - & 0.50 \\
\hline Section 9 inquiries(per day) & - & 0.50 \\
\hline Any other special work(per day) & - & 0.60 \\
\hline
\end{tabular}

Source: Departmental orders, Valuation Department

The criteria shown in the table 1.2 is applied by the regional offices to measure the performance of ADVs under the supervision of performance evaluation branch in the Head office. 
Example: If an Assistant District Valuer has done three land acquisition files, which include Six lands and attended four rent board meetings during a month, his eligibility of earning marks will be as follows;

Land acquisitions- $\quad$ Files $\quad 3 \times 3.0=\quad 9.00$

Units $\quad 6 \times .05=\quad 3.00$

Rent board- $\quad$ Meetings $\quad 4 \times .30=\underline{1.20}$

Total marks $\quad \underline{\underline{13.20}}$ (Category $=$ above average

level)

\subsubsection{Actual performance obtained by the ADVs}

The Table 1.3 shows the number of Assistant District Valuers attached to the Regional and District offices and actual performance standards achieved by them in the year 2010 .

Table 1.3 Actual Performance Levels of Employees

\begin{tabular}{|l|c|c|c|c|c|c|c|c|c|}
\hline Name of the & $\begin{array}{c}\text { Below } \\
\text { Region }\end{array}$ & 10 & $\%$ & 12.5 & $\%$ & $\begin{array}{c}12.5 \text { to } \\
17.50\end{array}$ & $\begin{array}{c}17.5 \text { or } \\
\text { More }\end{array}$ & $\begin{array}{c}\text { Tota } \\
1\end{array}$ \\
\hline Colombo Metro & 11 & $30 \%$ & 12 & $32 \%$ & 9 & $24 \%$ & 5 & $14 \%$ & 37 \\
\hline Colombo Western & 20 & $53 \%$ & 14 & $37 \%$ & 3 & $24 \%$ & 1 & $3 \%$ & 38 \\
\hline Western North & 8 & $23 \%$ & 11 & $31 \%$ & 13 & $26 \%$ & 3 & $9 \%$ & 35 \\
\hline Western South & 0 & $0 \%$ & 18 & $78 \%$ & 5 & $39 \%$ & 0 & $0 \%$ & 23 \\
\hline Southern & 12 & $29 \%$ & 17 & $40 \%$ & 10 & $21 \%$ & 3 & $7 \%$ & 42 \\
\hline Central & 3 & $8 \%$ & 10 & $27 \%$ & 19 & $24 \%$ & 5 & $14 \%$ & 37 \\
\hline North-Western & 7 & $24 \%$ & 8 & $28 \%$ & 8 & $31 \%$ & 6 & $21 \%$ & 29 \\
\hline Sabaragamuwa & 1 & $6 \%$ & 5 & $31 \%$ & 9 & $56 \%$ & 1 & $6 \%$ & 16 \\
\hline North-Central & 2 & $14 \%$ & 4 & $29 \%$ & 4 & $64 \%$ & 4 & $29 \%$ & 14 \\
\hline Uva \& East & 6 & $23 \%$ & 6 & $23 \%$ & 10 & $35 \%$ & 4 & $15 \%$ & 26 \\
\hline I/T unit & 0 & $0 \%$ & 0 & $0 \%$ & 10 & $82 \%$ & 1 & $9 \%$ & 11 \\
\hline Jaffna & 2 & $29 \%$ & 2 & $29 \%$ & 2 & $29 \%$ & 1 & $14 \%$ & 7 \\
\hline Total & 72 & $23 \%$ & 107 & $34 \%$ & 102 & $32 \%$ & 34 & $12 \%$ & 314 \\
\hline
\end{tabular}

Source: Valuation Department, 2010 monthly reports

In Colombo Metro region 30\% of the employees were at an unsatisfactory level and in Colombo western region it was 53\%. The percentage in Southern and Jaffna sub 